Man and Nature

L'homme et la nature

\title{
Reid and the Rights of Man
}

\section{Melvin T. Dalgarno}

Volume 4, 1985

URI : https://id.erudit.org/iderudit/1011837ar

DOI : https://doi.org/10.7202/1011837ar

Aller au sommaire du numéro

Éditeur(s)

Canadian Society for Eighteenth-Century Studies / Société canadienne d'étude du dix-huitième siècle

ISSN

0824-3298 (imprimé)

1927-8810 (numérique)

Découvrir la revue

Citer cet article

Dalgarno, M. T. (1985). Reid and the Rights of Man. Man and Nature / L'homme et la nature, 4, 81-94. https://doi.org/10.7202/1011837ar

Copyright (c) Canadian Society for Eighteenth-Century Studies / Sociéte canadienne d'étude du dix-huitième siècle, 1985
Ce document est protégé par la loi sur le droit d'auteur. L'utilisation des services d'Érudit (y compris la reproduction) est assujettie à sa politique d'utilisation que vous pouvez consulter en ligne.

https://apropos.erudit.org/fr/usagers/politique-dutilisation/ 


\section{Reid and the Rights of Man}

The Realist epistemology and Intuitionist moral philosophy which Thomas Reid defended on behalf of common sense in An Inquiry into the Human Mind on the Principles of Common Sense (1764), Essays on the Intellectual Powers of Man (1785), and Essays on the Active Powers of the Human Mind (1788), have some tendency to encourage an opinion that Reid's politics would have had a predominantly middle of the road if not reactionary cast. This view is quite mistaken. If Hume's onslaught on the tenets of conventional philosophy made him the enfant terrible of the Scottish Enlightenment, his politics had no such radical character. There is a rich irony in Reid occupying the role of the counter-revolutionary on the philosophical front of epistemology, when his attachment to the Rights of Man ideology would have made him an incongruously aged enfant terrible in Hume's eyes.

There is a similar paradox in the French reception of Reid's philosophy following the Restoration of the Monarchy in the Nineteenth-century when, under the direction of Victor Cousin, it was adopted officially as a vehicle for philosophical instruction. Jean-Pierre Cotten of the University of Caen has stressed the considerable part political ideology played in this. ${ }^{1}$ In the ultra-conservative climate of the restored Monarchy, there was an expressed need for philosophy which was free from and even an antidote to those ideas which were held to have contributed to the intellectual movements engendering the Revolution. Particularly offensive to leading thinkers who were seeking security in the restored order was the atomistic reductionism of the theory of ideas which brought in its 
train sensationalism and utilitarianism. If nothing worse, these philosophical positions were tainted with guilt by association. But in finding their champion in Reid, the proponents of the new ideology had found a philosopher firmly attached to the Rights of Man ideology who was known by his Scots contemporaries to have publicly supported the Revolutionary cause.

Knowledge of Reid's financial contribution to the National Assembly may have been confined to a relatively narrow circle, but the appearance of his name in The Glasgow Mercury, 5 July 1791, as one of four stewards for a public meeting advertised to celebrate on 14 July the anniversary of the Revolution, would have made his stance widely known. ${ }^{2}$ In a manuscript fragment carrying the draft of a portion of a letter to an unidentified correspondent, Reid declared:

I have been very long perswaded ${ }^{\circ}$, that a Nation, to be free, needs onely ${ }^{\circ}$ to [understand $d^{\mathrm{C}}$ ] know the Rights of Man. I have lived to see ${ }^{\mathrm{s}}$ this Knowledge spread far ${ }^{5}$ beyond my most sanguine hopes, and produce glorious Effects. God grant it may spread more and more and that $\left[\right.$ that $\left.^{\mathrm{r}}\right]$ those who taste the Sweets of Liberty may not turn giddy but make a wise and sober Use of it. ${ }^{3}$

This was written shortly after the meeting in 1791 of Friends to the Revolution in France. Reid who was 81 years old was conscious of bizarre elements in the prominent part he had played. After explaining how his participation had provoked an anonymous threatening letter, Reid wryly questioned his correspondent whether he thought it 'more odd that an old deaf Dotard should be announced as a Stewart ${ }^{\circ}$ of such a Meeting, or that it should give any Man such offence?'

A more serious question concerns the relation between Reid's attachment to the Rights of Man and the philosophy he had so patiently developed in response to the challenge of Hume's Treatise. If the attachment is not merely consistent with Reid's philosophy but rather something integral to it, then his conservative advocates in France of the 1820 's and 30's mistook not only their man but the implications of a philosophy based on a commitment to principles of common sense authority.

Fundamental to Reid's attachment to the Rights of Man is the judgment of every person that certain sorts of treatment from fellow human beings are due to him or her. Related to this is the view that the language of rights is apt for the expression of such judgments. When the first judgment, treated as a principle of common sense authority, is supplemented by the thesis about rights, one quickly realises how Reid regarded support for the Rights of Man. The firmness of his attachment is fully 
understandable when it is grasped that Reid held the Rights of Man to be coextensive with the moral duties we owe to our fellow human beings. Support for such rights is support for morality.

Reid opposed the view that the only rights a person had were either the legal rights accorded by a given system of positive law or rights which might be termed natural or moral in the sense that they ought to be accorded in such a system. ${ }^{4} \mathrm{He}$ considered the case where the legal jurisdiction under which he lived did not admit an action for the fulfilment of an unwritten and unwitnessed promise or bargain. In the event of the other party refusing to perform, Reid writes:

I find I am wronged[.] I cannot but think him under an obligation, altho ${ }^{\circ}$ the law does not oblige him [...] I am therefore very naturally led to conceive of some more extensive law which is more adequate to my notions of right and wrong. ${ }^{5}$

What is conceived here is not a reformed or extended legal system. It could well be that it would be a mistake to alter that system to allow actions on the basis in question. If it is, then this is not a legal right persons ought to have accorded them in that legal system. Rather, the more extensive law is, as Reid proceeds to make clear, the law of nature. The right which is violated is a natural right. The case is one where someone 'intuitively perceives' what is due to him, and 'feels that he is injured' where 'The feeling of his heart is grounded upon the Judgment of his Understanding. ${ }^{\prime} 6$ The law of nature, for Reid, was not some arcane matter reserved for the speculative enquiries of jurisprudentially inclined philosophers. It was the law of our nature, since Reid took the expression to denote the dictates of our faculty of moral judgment. ${ }^{7}$ He held this faculty to be natural: given our constitution and the circumstances of our lives, it was a spontaneous development whereby we acquired and applied the conceptions distinctive of morality. As such, it accompanies and is part of the growth of understanding:

Our moral conceptions and moral judgments are not born with us. They grow up by degrees, as our reason does. ${ }^{8}$

Thus, if someone does not develop the notions involved in the distinction between intended actions and involuntary ones, this person will be incapable of grasping the conception of an injury which merits resentment. But although Reid wished to stress the process of development involved in the mature display of this active power of the human mind, he was determined to castigate as a gross mistake the view that in order to 
understand your duty you needed to be a philosopher and metaphysician.

Reid lavished praise on Hugo Grotius whose De Jure Belli ac Pacis was published in Paris in 1625. He comments how this work drew after it, in the next 150 years, such a series of books by eminent authors that the connotation of the term natural jurisprudence is the work in this tradition. But it is important to notice what it is in the work of these writers that draws Reid's praise. He does not praise Grotius or the others for any subtle or refined chains of reasoning in establishing laws of nature; he praises them for improving the systematic presentation of the requirements of morality concerning the treatment of human beings by each other. Reid believed the key to this improved presentation to lie in the switch from the language of duties to that of rights, but the immediate point is that Reid's admiration for Grotius is perfectly consistent with what he taught his students at Glasgow:

The Rights and obligations of men grounded upon the laws of Nature do not require deep or subtile $\mathrm{O}$ reasoning to discover them. Nor indeed do they admit of it. ${ }^{9}$

Since Reid took natural jurisprudence to rest on the common sense foundation of the judgment we form of the conduct due to our fellow human beings and due to us from them ${ }^{10}$, and since he believed such apprehension to come so very level to the understanding of practically everyone, it is scarcely surprising that Reid should not credit Grotius with the innovation of uncovering the law of nature.

It is precisely this attachment to what the mature understanding conceives as due from fellow human beings, which explains Reid's puzzlement at the narrowness of Hume's treatment of justice. He writes of Hume:

He seems, I know not why, to have taken up a confined notion of justice, and to have restricted it to a regard to property and fidelity in contracts. As to other branches he is silent. He no where says, that it is not naturally criminal to rob an innocent man of his life, of his children, of his liberty, or of his reputation; and I am apt to think he never meant it. ${ }^{11}$

Reid evidently thought that if Hume accepted such actions as naturally criminal then he must accept (a) that these are cases of injustice, and (b) that this part of justice is natural. Reid has to establish (a), if he is to establish (b) which is the immediate object of his ad hominem argument. No doubt Hume would have insisted that the acts in question were 
naturally criminal in the sense of naturally vicious, and that the strength of revulsion we feel for such behaviour reveals the weight of the 'ought' in the judgment that we are to refrain from them. But it does not follow from this that Hume must admit some obligations of justice as not artificial, since Hume could deny that these naturally vicious acts are instances of injustice.

Hume's argument that the obligations of justice are artificial is an argument about what Hume (and not Reid) understands as an obligation of justice. Thus, if Reid is to force Hume to retract his view of the artificiality of justice, he must find an instance which Hume understands as an obligation of justice and show that it is a natural obligation. But if Hume is to escape Reid's objection in this way by pleading that Reid is guilty of ignoratio elenchi, the cost is indeed high, since he has been driven to take refuge in a highly technical, theory-laden notion of justice and injustice which is at variance with common language reflecting common sense conceptions. Robbing an innocent man of his life, his children, or his reputation are unequivocal cases of injustice according to common language and notions.

Reid, however, includes the following claim in his argument against Hume's treatment of justice:

The notion of justice carries inseparably along with it, a perception of its moral obligation. For to say that such an action is an act of justice, that it is due, that it ought to be done, that we are under a moral obligation to do it, are only different ways of expressing the same thing. ${ }^{12}$

Here it seems to be Reid who has departed from ordinary language. When I say that I ought to clean my shoes, it would be rash to take this as equivalent in meaning to my saying that I have a moral obligation to clean them, or that it is due to them or to some person, or that it is an act of justice to do so. What Reid writes is misleading since it suggests a commitment to this silly view. But to read the passage in this way is to miss the important point which Reid intends. The remark is to be read in the context of the judgment that $\mathrm{x}$ is owing to our fellow human beings, that it is a requirement of justice. When, in judgment, we bring the act under that conception, we are judging that it is due, that we ought to do it, and that we have a moral obligation to do it. In the case of a judgment involving the characteristic conception of justice, but not in the case of any and every judgment of what we ought to do, these are 'different ways of expressing the same thing', where 'the same thing' refers to the judgment in question. Where it is a judgment of justice, we judge that $x$ ought to be done in judging that it is due to another, or that it would be due to 
oneself on the part of another. If the judgment ' $x$ ought to be done' is taken sans phrase as a simple judgment, there is nothing in it to lead Reid to regard it as a judgment of justice. The nature of the conception applied in a judgment of justice makes it a complex judgment where we judge not only that $\mathrm{x}$ ought to be done simpliciter, but that it ought to be done as being owed to our fellow human beings as such, or as members of our family, or as members of the political community in which we live. ${ }^{13}$

Here, as elsewhere in Reid's philosophy, it is necessary to attend to the part which conceptions play. Once this is noticed, it is evident why Reid should have been so puzzled by the narrowness of Hume's treatment of justice. Could Hume have challenged as a principle of common sense the judgment of human beings that they ought not to be murdered, where they conceive that as something owed to them by their fellow human beings?

There are, of course, analyses of rights under which it is simply not true that we have a right not to be murdered. An example is the traditional vinculum juris conception of a right where the chain manacled to the wrist of the party under the obligation is held freely in the hand of the other party who can hold fast, binding the other to performance, or can let go the chain, releasing the other from the obligation. But in jurisdictions where it is a criminal wrong to kill someone, irrespective of that person's consent, the thesis that there is a legal right not to be murdered can be maintained only if one gives up the notion that waivability is a necessary element in a right. Similarly, there is no right not to be murdered on a version of the so-called Will Theory of Rights like H.L.A. Hart's, which makes the attribution of a right depend on the putative right holder having some element of sovereignty or control over another's duty. ${ }^{14}$ I do not have in law, any more than I would have in morals according to Reid, such control over your duty not to murder me that it depends on my will whether or not you have this duty.

What Hume would have said about this is not altogether clear, although he had some tendency to favour a lawyer's way of talking rights and obligations. Thus in Bk. III of the Treatise, Hume makes the point that in contrast to cases of natural virtue and vice which may vary by almost imperceptible degrees, the artificiality of the rules of justice is confirmed by the fact that they involve a concept of obligation which does not gradate:

For whatever may be the case, with regard to all kinds of vice and virtue, 'tis certain, that rights, and obligations, and property, admit of no such insensible gradation, but that a man either has a full and perfect property, or none at all; and is either entirely oblig'd to perform any action, or lies under no manner of obligation. ${ }^{15}$ 
This carries the suggestion of the vinculum juris conception of obligations with correlative rights, since in terms of the constitutive rules of the practice, legal or moral, of binding oneself to another party, it is simply a matter of operative facts whether or not an agent is subject to such an obligation. There are no half obligations, or half rights of this form. Reid who did not employ the concept of vinculum juris obligations and rights, is committed to the view that the obligations of justice gradate; he holds in a celebrated passage in his chapter 'Of Systems of Natural Jurisprudence' that it is difficult to draw a sharp distinction between justice and humanity, identified as spheres of perfect and imperfect rights, since 'like the colours in a prismatic image, they run into each other'. ${ }^{16}$ This surely implies gradation on either side of the line. The idea of gradation also fits the interpretation given here of Reid's understanding of judgments of justice. Though there is some tendency to regard something as being either due to you or not due to you, we do distinguish degrees in such judgments. ${ }^{17}$ Some things are perceived as much more strongly owing than others.

It was the unfortunate tendency of some of Reid's followers to traduce the positions of opponents under the banner of vindicating principles of common sense. Certainly there are no grounds for launching an attack on an analysis of rights such as the one Hart gives, on the grounds that it is repugnant to common sense in denying a right not to be murdered. Hart's is a penetrating analysis of a conception of rights which evolved from Roman law into modern municipal systems, and on which several moral and political philosophers, like Hobbes, have drawn quite valuably. The point is simply that other ways of talking about rights have become established exhibiting a different logical basis. Reid's support for another way of talking and his contribution to clarifying its logical basis is something which has been insufficiently recognized, no doubt because so much that is of value in this connection remains unpublished in his manuscripts.

Reid has a strikingly modern view of the language of rights, in regarding it as providing shorthand expressions for what would require many words if we were to choose the most direct and natural language. ${ }^{18}$ In MS 2131/8/IV/1 where he develops this idea, Reid shows that he will have no truck with any view that rights denote qualities of a person or thing, real relations, or mental phenomena. Rather, the language of rights offers a short technical way of mapping the position of parties relative to what in natural language we might express as the requirements of law or morality. Thus, if the legal system requires me not to murder you we can express your position relative to this requirement by saying that you have a right that I should not murder you ${ }^{19}$; and my position can be ex- 
pressed by saying that I have no right to murder you. The language of rights is used to signify what is within and what is without the bounds of such a requirement. It is in this way that Reid upholds the claim that the extent of men's rights against each other can be taken from the extent of their duties to each other; while the extent of what Reid calls a person's 'rights of liberty' can be taken by considering the extent of the duties incumbent on that person ${ }^{20}$. What I have a duty to do, I have no right to forbear; what I have a duty to forbear, I have no right to do. What I have no duty to do, I have the right to forbear; what I have no duty to forbear, I have the right to do. Reid has a firm grasp on the logic of this shorthand way of expressing a person's position relative to the presence or absence of requirements incumbent on that person. He does not, for instance, make the slip which one finds in people whose inexperience with this shorthand way leads them to deny a right to pay taxes on the grounds that they have no right not to pay.

While it is perfectly true, as Reid claims, that the extent of someone's rights against others can be taken from the extent of the duties others owe to him, some care is needed in using this conception of a right in mapping relative to requirements in law and morals. If it is a requirement that I clean my shoes, we do not want to say that my shoes have a right that I clean them. Or again, if the executioner is required to chop off my head, we would not want to say that I have a right that he should do so. ${ }^{21}$ Reid seems to cover the first of these cases by insisting that the language of rights is used to map the position of persons relative to requirements. He covers the second case in MS 2131/7/VII/1c by insisting that the language of rights is used in accordance with the criterion of what is beneficial: 'We do not say that a Thief has a right to be hanged, because it is not supposed that any man would chuse ${ }^{\circ}$ to be hanged'. It might seem that these are mere ad hoc qualifications to block entailments which would otherwise carry in switching from the active form of the language of duty ('A ought to do $x$ to $B^{\prime}$ ) to the passive formulation which lies behind the language of rights ('B ought to have $x$ done to him/her/it by $\left.A^{\prime}\right)$. But such an objection mistakes Reid's position, which is that the language of rights is apt for mapping the position of a party relative to the requirements on others which are owed to him/her.

The conception involved in judgments of justice is of what is due to a person. It is here that Reid has the resource he requires to meet the charge of ad hoc restrictions. There is a clear distinction between perceiving that an act with respect to me but not due to me is required of someone, and perceiving that an act with respect to me or someone else is required of someone as due to me. This is a cumbersome way of expressing the point that if I promise my mother that I will meet my father after work, the re- 
quired act is with respect to my father i.e., meeting him, while due to my mother who is the promisee.

It is an objection frequently brought against the Interest or Beneficiary theory of rights that it lacks the resources to mark the distinction between the person specified to be affected by an obligatory act and the person to whom the obligatory act is owed. But if I understand it correctly, Reid's theory does not have this problem; he ties the language of rights to justice in the broad sense where we map in accordance with a conception of what is required as owed to others.

This resource is of considerable assistance in clarifying the relation between Reid's arguments in MS 3061/6, 'Some Thoughts on the Utopian System,' from which 'On the Danger of Political Innovation' was abstracted, and his earlier claims about Governments forfeiting their right to obedience under circumstances of 'a general and violent Oppression' which free subjects from the obligation to obey and entitle them to resist in an effort to defend their rights. ${ }^{22}$ This earlier view might appear inconsistent with the later argument stressing the obligation of subjects to obey an established Government when the general harm of disobedience and revolution would outweigh the harm done by the Government's oppression. Here we must distinguish the judgment of what is due to the Government with respect to obeying it, and of what is due to our fellow men and citizens with respect to obedience to the Government. Thus distinguished, it is not the argument of MS 3061/6 that the Government does not forfeit its right to the obedience of subjects under certain circumstances. It can cease to have that right even when it remains a requirement of morality that subjects should not actively resist the Government; this being a requirement subjects may owe to each other.

In his chapter 'Of Systems of Natural Jurisprudence' in the Active Powers, Reid gives a number of reasons why natural jurisprudence should not be confined to treating perfect rights but should be extended to cover imperfect rights. Perfect rights, he explains, name the claims of strict justice while imperfect rights name the claims of charity and humanity. Reid gives as examples of perfect rights, our right to our lives and the integrity of our members, to liberty and private judgment, to fair dealing and truth from others; we have imperfect rights to social intercourse and civil treatment, to offices of humanity from others which cost them little or no trouble, and even to offices of some expense in cases of distress, to kindness and liberality suited to our needs and merit, and to gratitude from those we have benefited. ${ }^{23}$ Reid's manuscripts betray some uncertainty about how to ground this distinction since he rejected traditional ways of drawing it. ${ }^{24}$ In the Active Powers, however, Reid is quite adamant that rights are to be ascribed to people relative to the re- 
quirements of morality in the area traditionally denominated as the sphere of imperfect obligation. There is no suggestion of an earlier hesitation betrayed in a manuscript where he describes such rights as 'a shaddow $^{\mathrm{o}}$ of Right' ${ }^{25}$ Reid, finally, moved in the direction diametrically opposed to that which J.S. Mill was to take. Mill rested the distinction between perfect and imperfect obligations on the former, but not the latter, giving rise to correlative rights in others. Imperfect duties were described by Mill as cases where 'though the act is obligatory, the particular occasions of performing it are left to our choice, as in the case of charity or beneficence, which we are indeed bound to practise, but not towards any definite person, nor at any prescribed time'. ${ }^{26}$ Mill, I think, is confused in a way Reid was not: individuals can have rights to our charity and beneficence. The conceptions involved in judgment need careful attention.

The judgment that it is a requirement of morality that we should be charitable, has to be distinguised from the judgment in a particular case that my assistance is due to some person who requires it. Only in the latter case is our judgment aptly expressed by the ascription of a right to the person in distress. Mill correctly appreciated that one could not jump from the view that it betrayed a defect of moral character not to make any charitable donations, to the claim that Oxfam has a right to so many dollars from us. But this blinded him to what Reid appreciated. When we are confronted in the street by a woman who tells us she has lost her child, particular conceptions attach to our judgment that we ought to give assistance. We do not bring it under the conception of granting a favour, but rather of doing what is due to the woman in such circumstances. This is the judgment which, on Reid's view of the language of rights, is aptly expressed by saying that the woman has a right to our assistance.

Given Reid's understanding of natural jurisprudence as resting on the common sense principle of what our moral faculty dictates regarding what is owed to our fellow human beings, it is quite clear why he should have upheld the view that natural jurisprudence with its object of teaching the rights of men should not confine itself to what were traditionally conceived as perfect rights. This is demanded by the actual judgments we do make, and for a contention like Reid's:

The right of an innocent man to the necessaries of life, is, in its nature, superior to that which the rich man has to his riches, even though they may be honestly acquired. ${ }^{27}$

Our judgments of what morality requires reflect this gradation where a 
so-called imperfect right is perceived as something more strongly owing than perfect rights to property.

Commenting on the American Declaration of Rights in the second half of the eighteenth century, Bentham declared: 'Who can help lamenting, that so rational a cause should be rested on reasons, so much fitter to beget objections, than to remove them $?^{\prime 28}$ This offers a salutary reminder that a commitment to objectives morally prescribed need not be accompanied by approval for the employment in this connection of the language of rights. Thus, in the attack on the French Declaration of Rights contained in his Anarchical Fallacies, Bentham deplored the switch from judgments expressed in the language of ought and ought not, to the language of rights. This was to move from the language of sound sense to a language of smooth nonsense which carried daggers with it. ${ }^{29}$

This may suggest that a wedge might be driven between Reid's attachment to the dictates of our moral faculty, as a principle of common sense philosophy, and his attachment to the Rights of Man. Such a move would produce a Reid suitably disinfected for French consumption in the post-Revolutionary era. But it is not a move which can be justified. Reid does not switch from the judgment that the general happiness requires Governments not to pass certain laws to the proposition that citizens have a right that Governments should not; where the latter proposition carries entailments and implications which are not contained in the original judgment. Attention to Reid's use of the language of rights as a shorthand dispels any such notion. Expressed in this language of rights, the proposition that somebody has a right to something says no more than the judgment that it is due to him.

Bentham is rightly regarded as a great demythologiser who rent the veil of mystery surrounding the law and such notions as legal rights and duties. But Reid has unrecognised claims as a demythologiser of natural law and natural rights. That Bentham failed to take Reid's measure is probably an effect of the analysis of rights language contained in Reid's manuscripts being assumed rather than argued in the chapter of the Active Powers which treats natural jurisprudence. Its acceptance in our everyday speech amply confirms the view that the language of rights which Reid explains is a natural, straightforward language, well-suited to the judgments it is used to express.

In this straightforward language, support for the Rights of Man amounts to supporting morality. ${ }^{30}$ As Reid's response to this aspect of the early stages of the French Revolution is no aberration of advancing years, his later admirers in that country did, in this respect, mistake both 
their man and the implications of a philosophy based on a commitment to principles of common sense authority.

\author{
MELVIN T. DALGARNO \\ University of Aberdeen
}

\title{
Notes
}

1 Jean-Pierre Cotten, 'La philosophie écossaise en France avant Victor Cousin: Victor Cousin avant sa rencontre avec les Écossais', a communication to the Colloque Victor Cousin ... à Sevres, February 1982; and 'La 'Réception' d'Adam Smith chez les derniers Idéologistes et dans la 'Nouvelle Philosophie', a paper read at the Conference Adam Smith and Continental Thought, Edinburgh University, March 1983.

2 This publicity is clearly related to subsequent events which have been represented as Reid's bowing to the storm. For a more judicious account of what is clearly a more complex matter, see J.C. Stewart-Robertson's 'Sancte Socrates: Scottish Reflections on Obedience and Resistance', Proceedings of the Canadian Society for Eighteenth-Century Studies, I, pp. 72-74.

3 Aberdeen University Library, MS 2131/3/III/8. The notations explained below are used in this or subsequent quotations from Reid's manuscripts. They are designed by the General Editor of the Reid Publication Series.

${ }^{\circ}$ as spelled in the original text.

[.] punctuation supplied in the interests of clarity or sense.

[ ${ }^{\mathrm{C}}$ ] a cancellation or stroke out which is nevertheless still decipherable.

$s$ a word superscribed above the regular line of text.

$\left[{ }^{r}\right]$ the word is repeated without cancellation in the text.

4 While Bentham insisted on all rights being creatures of positive law - a right being either an actual legal right or a misleading way of talking about a legal right you ought to have - there was some tendency among later utilitarians to admit talk of rights for this latter conception. This was taken over into the Idealist school by T.H. Green. Cf. T.H. Green, Lectures on the Principles of Political Obligation, ed. Bosanquet, with a Preface by A.D. Lindsay (London, 1910), pp. 33-34.

5 MS 2131/8/IV/1.

6 MS 2131/4/III/18. Cf. Essays on the Active Powers of the Human Mind, ed. Brophy, Essay V, ch. 5, p. 416.

7 '... the dictates of our Moral faculty are a law to which we are Subjected by the constitution of our Nature, even without considering our Relation to the Deity' (MS 2131/8/IV/1).

8 Active Powers, Essay V, ch. 5, p. 405. See also Essay V, ch. 1, pp. 369-70. 
9 MS 2131/8/IV/4.

10 The self-evident axiom which links these judgments is the fourth in Reid's list of particular axioms in his chapter 'On the First Principles of Morals'. Reid's comment 'It is not want of judgment, but want of candour and impartiality, that hinders men from discerning what they owe others. They are quicksighted enough in discerning what is due to themselves' draws attention to a kind of heuristic priority in the judgment of what is due to self, but he does not give it logical priority over the judgment of what is due to others,

11 Active Powers, Essay V, ch. 5, p. 418.

12 ibid., p. 413.

13 J.S. Mill argued in ch. 5 of Utilitarianism that the judgment that $x$ was a duty of justice was complex; it involved three elements: (i) that $x$ ought to be done; (ii) that an agent might rightfully be compelled to do $x$; and (iii) that omitting $x$ would violate the right of some assignable party.

14 H.L.A. Hart, 'Bentham on Legal Rights' in Oxford Essays in Jurisprudence, Second Series, ed. A.W.B. Simpson (Oxford: Clarendon, 1973).

15 D. Hume, A Treatise of Human Nature, ed. L.A. Selby-Bigge (Oxford, 1888/1964), p. 529.

16 Active Powers, Essay V, ch. 3, p. 385.

17 In a lecture published in the Juridical Review vol. 63, David Daube examines how the symbolism of the scales of justice 'expresses a deep-rooted tendency to see no shades between black and white, to admit no degrees of right and wrong, to allow no distribution of loss and gain among several litigants, to send a party away either victorious or defeated'.

18 For a fuller account of Reid's analysis of the logic of the rights language he employs, see my 'Reid's Natural Jurisprudence: the Language of Rights and Duties', published in the Edinburgh University Press Festschrift volume in honour of G.E. Davie, Philosophers of the Scottish Enlightenment, ed. Vincent Hope (1984).

19 If we did not regard the legal protection involved in the prohibition on murder as due to each member of society, the bare existence of the legal requirement might not warrant the mapping in terms of the rights of individuals against others.

20 My Right to do such an Action implies that I may do it without transgressing the Law or being obnoxious to censure[.] And this Right extends 1 To all Actions that I am obliged to do, 2 To the forbearing all unlawfull ${ }^{\circ}$ actions, but 3 Most properly to all actions that are indifferent, which I may do or omit without a trespass' (MS 2131/7/VII/1c). This account is to be preferred to the misleading assertion on p. 379 of the Active Powers which appears to make liberty-rights in one party correlate with duties on others not to hinder.

21 If I had paid him to use his best skill, I would have the perfect right that the headsman should take care not to botch the job. If I judged that in humanity he owed this to me anyhow, it would be my judgment that I had an imperfect right to this. But neither of these rights is the right to be executed. 
23 Cf. MS 2131/8/IV/1.

24 This is explored more thoroughly in my 'Reid's Natural Jurisprudence: the Language of Rights and Duties,' op. cit..

25 MS 2131/7/VII/1b of circa 1770.

26 J.S. Mill, Utilitarianism, ed. M. Warnock (London and Glasgow: Collins, 1962/70), p. 305.

27 Active Powers, Essay V, ch. 5, p. 423.

28 Bentham, An Introduction to the Principles of Morals and Legislation, ed. Burns and Hart (London: Athlone, 1970), p. 311.

29 Bentham, Works, ed. Bowring, vol. II, p. 524.

30 Provided, of course, the list of rights is soundly based. 